\section{Hypothalamic hyperphagia: Loss of weight through voluntary exercise}

\author{
GORDON SPIES \\ Indiana State University, Terre Haute, Ind. 47809
}

Six hypothalamic hyperphagic rats were housed in activity cages for periods ranging from 14 to 28 days. Five Ss lost weight during the period, and rate of gain of the sixth was sharply attenuated. On return to their home cages, Ss' weight gain returned to above-normal levels. It is suggested that in a free environment the static phase of hypothalamic hyperphagia might not be attained and that it is an artifact of the manner in which the animals are housed.

Animals with bilateral lesions of the ventromedial nuclei of the hypothalamus (VMN) markedly increase food intake and gain weight rapidly until they reach an obesity plateau, when food intake drops to little more than that of normal animals. The former period has been called the dynamic phase and the latter the static phase (Brobeck, 1960). It has also been shown that while such animals will work for their food during the dynamic phase, they will not do so during the static phase (Miller, Bailey, \& Stevenson, 1950). Morgane (1962) refers to them as "slothful."

However, animals on which such experiments are conducted are usually housed in cages that afford little opportunity for exercise. In the case of the rat, the most common experimental $S$, the cage is generally about $10 \times 7 \times 7$ in. The purpose of this study was to ascertain if, given the opportunity, VMN-lesioned rats would counteract the effects of hyperphagia by voluntarily taken exercise.

\section{SUBJECTS}

From a larger study on hypothalamic hyperphagia (Spies, 1970) ${ }^{1}$, six hyperphagic female Long-Evans hooded rats were selected at random, with the proviso that the average daily weight gain of each exceed $2.5 \mathrm{~g}$; the range of weight gain for normal animals is $0-2 \mathrm{~g}$ per day.

\section{PROCEDURE}

All Ss were weighed daily throughout the study. At a period ranging from 4 to 11 weeks after bilateral electrolytic VMN lesioning, $S$ was taken from its home cage and placed in a Wahman activity cage in which the door leading from the cage to the wheel had been enlarged. Food and water were available at all times. Revolutions of the activity wheel were recorded daily. At the end of a 2-, 3-, or 4-week period, $S$ was returned to its home cage.

\section{RESULTS}

Table 1 shows that during the period between lesioning and placing in activity cages the average daily weight gain of Ss (Column 4) was $4.00 \mathrm{~g}$ (range 2.65 to 5.93), while during the period in the activity wheel the average weight loss (Column 8) was $1.98 \mathrm{~g}$ (range +1.00 to $-4.33 \mathrm{~g}$ ). It should be noted that in the case of S 34, there was no actual loss of weight during the period in the activity wheel, but the average daily gain was sharply attenuated to $1.00 \mathrm{~g}$, which is within the range for normal animals, as opposed to an average daily gain of $2.65 \mathrm{~g}$ prior to placement in the activity cage.

On return to their home cages, with one exception, the average daily gain of Ss However, there was no consistency in that returned to beyond normal levels. two Ss, Nos. 19 and 34, exceeded their preactivity rates of gain, while the remainder failed to attain their previous rates, and the average daily gain of S 18 remained within the normal range at $1.52 \mathrm{~g}$. However, the postactivity rate of gain appeared, as one might expect, to be a function of how close the animal was to its ultimate obesity level.

These results show that, given the opportunity to exercise, rats do counteract the weight-gain effects of hyperphagia. This finding does not negate the conclusion of Hoebel \& Teitelbaum (1961), that some stimulus correlated with obesity controls food intake, and accounts for the fact that weight gain levels off in the static phase. However, it does suggest that in a free environment animals might never reach the static phase and that this phase, including its attendant slothfulness, is an artifact of the manner in which the animals are housed. To ascertain this, a study is currently in progress in which hypothalamic hyperphagics are housed in activity cages throughout their life span.

\section{REFERENCES}

BROBECK, J. R. Regulation of feeding and drinking. In J. Field (Ed.), Handbook of physiology. Sec. 1, Vol. II. Baltimore: Waverly Press, 1960. Pp. 1197-1206.

HOEBEL, B. G., \& TEITELBAUM, P. Weight regulation in normal and hypothalamic hyperphagia rats. Journal of Comparative \& Physiological Psychology, 1966, 61, 189-193. MILLER, N. E., BAILEY, C. J., \& STEVENSON, J. A. Decreased "hunger" but increased food intake resulting from hypothalamic lesions. Science, 1950, 112, 256-259.

MORGANE, P. J. Hypothalamic and rhinencephalic mechanisms on the regulation of caloric intake. Paper presented at XII International Congress Physiological Sciences, Leiden, The Netherlands, September 1962.

SPIES, G. Insulin hypoglycemia and hypothalamic hyperphagia. Psychonomic Science, 1970, 20, 311-312.

\section{NOTE}

1. The study referred to was supported by Small Grant M15770-1 from the National Institute of Mental Health, United States Public Health Service.

Table 1

\begin{tabular}{|c|c|c|c|c|c|c|c|c|c|c|}
\hline $\begin{array}{c}\text { S } \\
\text { No. } \\
1\end{array}$ & $\begin{array}{c}\text { Weight } \\
\text { on } \\
\text { lesioning } \\
\text { (grams) } \\
2 \\
\end{array}$ & $\begin{array}{l}\text { Days from } \\
\text { lesioning to } \\
\text { placement } \\
\text { in activity } \\
\text { cage } \\
3\end{array}$ & $\begin{array}{l}\text { Average } \\
\text { daily } \\
\text { weight } \\
\text { gain } \\
\text { (grams) } \\
4 \\
\end{array}$ & $\begin{array}{c}\text { Weight on } \\
\text { placement } \\
\text { in activity } \\
\text { cage } \\
\text { (grams) } \\
5\end{array}$ & $\begin{array}{c}\text { Days in } \\
\text { activity } \\
\text { cage } \\
6\end{array}$ & $\begin{array}{c}\text { Average } \\
\text { daily } \\
\text { revolutions } \\
7 \\
\end{array}$ & $\begin{array}{c}\text { Average daily } \\
\text { rate of } \\
\text { loss/gain } \\
\text { in activity } \\
\text { cage (grams) } \\
8 \\
\end{array}$ & $\begin{array}{c}\text { Weight } \\
\text { on removal } \\
\text { from } \\
\text { activity cage } \\
\text { (grams) } \\
9\end{array}$ & $\begin{array}{c}\text { Average } \\
\text { daily } \\
\text { weight gain } \\
\text { postactivity } \\
\text { (grams) } \\
10\end{array}$ & $\begin{array}{c}\text { Ultimate } \\
\text { obesity } \\
\text { level } \\
11\end{array}$ \\
\hline 18 & 270 & 49 & 3.06 & 420 & 21 & 481 & -1.19 & 395 & $1.52(21$ days $)$ & 460 \\
\hline 19 & 218 & 35 & 3.14 & 328 & 14 & 621 & -2.35 & 295 & 3.42 ( 14 days) & 530 \\
\hline 23 & 292 & 77 & 3.96 & 597 & 28 & 543 & -3.28 & 505 & 3.66 (28 days) & 640 \\
\hline 26 & 215 & 49 & 5.93 & 506 & 14 & 496 & -1.71 & 482 & 2.86 ( 14 days) & 593 \\
\hline 34 & 226 & 63 & 2.65 & 393 & 28 & 347 & +1.00 & 421 & 3.10 (28 days) & 552 \\
\hline \multirow[t]{2}{*}{39} & 238 & 63 & 5.28 & 571 & 21 & 769 & -4.33 & 480 & 2.23 (21 days) & 580 \\
\hline & & & $M=4.00$ & & & $M=543$ & $\mathrm{M}=-1.98$ & \multicolumn{2}{|c|}{$M=2.80$} & \\
\hline
\end{tabular}

